\title{
T. Villanueva, Escena de la película Gigante (Edición bilingüe, traducción de Rafael Cabañas Alamán), Madrid, Catriel, 2005, 96 pp.
}

Scene from the Movie GIANT, de Tino Villanueva, es un poemario que ensalza el desgarro de la identidad chicana y su problemática, y que surge a raíz de la ya clásica y galardonada película Gigante (1956), protagonizada por Rock Hudson, Elizabeth Taylor y Dennis Hopper. La edición que aquí presentamos supone una puesta de largo de la obra de Villanueva y un intento de volver la mirada a las víctimas directas de aquellos conflictos, presentando, por primera vez, una traducción íntegra del poemario, prologada y vertida al español por Rafael Cabañas Alamán, profesor del Departamento de Lenguas Modernas y Arte de Saint Louis University (Campus de Madrid) y especialista reconocido en los estudios de traducción (inglés-español).

Ciñéndonos a la pura realidad vital del autor, hemos de señalar que nació en el pueblo de San Marcos, Texas, en el seno de una familia de ascendencia mexicana, de trabajadores rurales, emigrados en busca de un futuro mejor del otro lado del Río Grande. Esa es, sin duda, la causa primera del impacto que producirá en su niñez la contemplación de la escena final de la película, clave, al propio tiempo, para comprender la esencia más íntima de su poemario: en un aislado café de una carretera de Texas, un fornido y arrogante camarero se niega a servir a una pobre familia de mexicoamericanos. El desenlace no viene sino a insistir en el triunfo de la fuerza bruta, alentada por una irrespirable atmósfera racista.

Una imagen, una escena de una película cualquiera en la memoria durante décadas, apenas unos instantes clavados en el alma y recuperados tiempo después, quizás en ese momento en el que somos lo suficientemente mayores y maduros para comprender alguno de tantos porqués brotando a lo largo de la vida. El bebedizo mágico, la magdalena que nos trasporta hacia el pasado... ("Que el guión revele: que en el acto de contar/me lanzo hacia delante en el tiempo", grita Villanueva)

Pero, ¿por qué aquella escena y no otra?, ¿por qué permaneció latente durante tanto tiempo? "El revivir de la memoria", como su nostalgia, solo son comprensibles con el paso de los años; hasta entonces no podremos ni tan siquiera vislumbrar los efectos que tuvieron en nosotros unas circunstancias y no otras. De hecho, el propio autor ya nos advierte y sitúa, en esta línea interpretativa, desde los preliminares del poemario, puesto que "estos poemas relatan un incidente del pasado y están concebidos para leerse en consecuencia".

"Sobre estas escenas (la real y la cinematográfica) y sobre la vida que fluye hacia el pasado para comprender sus silencios", se articula el poemario, dividido en cinco partes que suman un total de 21 poemas, a los que antecede otro a modo de prefacio, en los que se poetiza la temática concreta de la discriminación hacia los mexicoamericanos. Desde la angustia, la insatisfacción y la protesta, inicialmente agria, clama justicia, pero no venganza; la serenidad que pretendió atribuir a sus versos continuará en las escenas que se suceden.

Así un autor chicano en Marlborough Street, una ciudad, Boston, una 
película en el recuerdo y apenas unas hojas en blanco que lo inmortalicen para siempre. Un cruel y paradójico juego. Escribir, ese eterno dilema entre aliviar, a modo de catarsis, el intenso dolor momentáneo ("estás a salvo para siempre en las/ palabras mismas que has elegido ser", apunta el propio Villanueva) y perpetuarlo al plasmarlo para la eternidad. Ese sentimiento de obligación que le invade, de obligación para con los otros, sus paisanos, aquellos que comparten la misma dolorosa experiencia.

Difícil tarea, entonces, sin duda, aquella a la que hubo de someterse el traductor, tratando de adentrarse, no solo en un terreno tan conflictivo y espinoso como el de las tensiones raciales americanas sino en el intento de trasladar a otra lengua unos sentimientos y unas sensaciones clavadas en la memoria personal del autor y colectiva de todo un pueblo.

Estamos, pues, frente a una lectura a dos voces o aún ante un triple juego que forman la película y las experiencias que nacen de la misma en un adolescente que comienza a comprender su realidad, por un lado, y la relación de amistad, confianza y comprensión mutua que suscita la traducción, por otro. Y de esa manera lo siente el propio Rafael Cabañas al afirmar: "Así, de la noche a la mañana, impactado por la fuerza poética de la obra, me vi envuelto en la grata pero nada fácil tarea de empezar a verter al español Scene from the Movie GIANT".

Un intento de permanecer siempre leal a la voz poética del creador "arma fiel ante la discriminación e injusticia que hiere, motiva y da sentido a la voz poética", alentar de una injusticia, voz alzada ante la adversidad, clamor de los que sufren, hispanos en mitad de la nada, lejos de su patria y necesitados de voz, de una voz que debiera hablar su misma lengua, para identificarse con ellos, para sentir por ellos, en suma, para gritar por ellos. Este debió ser el aliento que empujara a Rafael Cabañas, más allá de aquel de la amistad. Una poesía nacida de una tal esencia no podría entenderse sin su correspondiente traducción al español.

Así le hallamos en su papel de transmisor y mediador; pero también en ese otro que provoca una eterna insatisfacción y una innegable inseguridad: el del traductor, el traductor traidor, el traductor infiel, el usurpador de otras palabras, boca que da voz a unas palabras que no son suyas.

Y así lo siente él mismo cuando no duda en confesar "si bien en todo momento he intentado ser lo más fiel, en lo posible, al texto original, no he dejado de sentir la sensación de estar ocultándome bajo la piel de un transgresor de la palabra".

Por eso, si, para Roland Barthes, el crítico es un escritor aplazado, otro tanto podríamos afirmar del traductor; pues, a pesar de no haber creado algo propio, deberá ser capaz de sentir y transmitir idénticas sensaciones, a través de su traducción.

En suma, una obra que invita a la reflexión y que, en la tradición poética más clásica, sumerge al lector en un océano de dudas, de inquietudes respecto de una situación que se prolonga en el tiempo y el espacio haciendo de estos personajes humildes, héroes con vigencia universal. Fidelidad absoluta y destacable, en la propia traducción, respecto al original, en un intento de 
mantener viva la esencia que los hizo surgir, desde el dolor que pretende conservar pasando por "el vacío que traspasa cada pensamiento". Conseguido el objetivo, el poeta como, seguramente, el traductor exclamarán "Ahora soy porque escribo".

Miriam López Santos 